\title{
Imposex in the dogwhelk (Nucella lapillus): 22-year monitoring around England and Wales
}

\author{
E. E. Manuel Nicolaus • Jon Barry
}

Received: 16 March 2015 / Accepted: 2 November 2015 /Published online: 10 November 2015

(C) The Author(s) 2015. This article is published with open access at Springerlink.com

\begin{abstract}
Six imposex surveys in the dogwhelk (Nucella lapillus) have been conducted over the past two decades to assess legislation effectiveness controlling the use of tri-butyl tin (TBT) by the maritime shipping industry. This study firstly analysed the results of the 2014 survey and secondly carried out a trend assessment of the same 88 sampled sites between 1997 and 2014 of which 65 showed statistically significant reductions. To highlight the magnitude of change, the Vas Deferens Sequence stages (VDS) of the same 56 sites sampled in 1997 and 2010 showed that the Vas Deferens Sequence Index (VDSI) reduced statistically significantly from 2.89 and 0.42 , respectively. These data confirm that the legislation enacted, latterly through the International Maritime Organization (IMO) during 2003 to 2008 , has been effective in progressively reducing the impact of TBT in the marine environment. Nevertheless, the 2014 results show that two of 18 sampled sites (Gurnard Bay and St. Mawes) are still above the Ecotoxicological Assessment Criteria (EAC) derived for TBT $(\operatorname{VDSI} \leq 2)$.
\end{abstract}

Keywords TBT pollution · Imposex · Nucella lapillus . Marine monitoring · England and Wales

Electronic supplementary material The online version of this article (doi:10.1007/s10661-015-4961-0) contains supplementary material, which is available to authorized users.

E. E. M. Nicolaus $(\bowtie) \cdot J$. Barry

Centre for Environment, Fisheries and Aquaculture Science,

Lowestoft, Suffolk NR33 0LB, UK

e-mail: manuel.nicolaus@cefas.co.uk

\section{Introduction}

Imposex is the imposition of male sexual characteristics on female gastropods and has been found to be one of the most sensitive indicators of environmental tri-butyl tin (TBT) exposure. The incidence of imposex was found to be caused by TBT when used as a biocide in marine antifouling paints for both yachts and large ships in the 1960s (Waldock et al. 1988). In Nucella lapillus, the effect is dose related and severe imposex can lead to sterility in females and detrimental reproductive effects on both individuals and populations. The process and characterisation of imposex have been well documented (see, for example, Gibbs et al. 1987; Oehlmann et al. 1991; Santos et al. 2002). Dogwhelk monitoring is also an established biological effect monitoring tool used by many Oslo and Paris Convention (OSPAR 2013a) contracting countries to assess good environmental status by 2020 for the Marine Strategy Framework Directive.

Over the last two decades, legislation has been introduced, firstly to control the use of TBT-based antifouling paints on yachts and, more recently, the prohibition of the use of these biocides on large ships. Imposex (in N. lapillus) surveys like those undertaken in 1992 and 1997 for England and Wales were conducted to establish data to support and justify United Kingdom (UK) and European Union (EU) legislation restricting the use of organotin compounds. In 2003, the International Maritime Organization (IMO) introduced legislation banning the use of organotin on all ships. As seagoing vessels may be repainted with antifouling paint only every 
5 years, this ban was implemented during 2003-2008. Surveys conducted in 2004, 2007 and 2010 span the period prior to and during the implementation of the IMO worldwide ban (2003-2008) on the use and application of TBT antifouling paints on all commercial shipping, and therefore serve as a time series allowing us to measure the effectiveness of the legislation. The 2014 survey aimed to study the effectiveness of these measures, 6 years after TBT-containing antifouling paints were fully removed from use.

The surveys of 1992, 1997, 2004 and 2007 established a network of 102 sampling sites (Table 1) across England and Wales. The 2007 survey used 86 sites, reduced in number either because dogwhelks had disappeared from some sites or because some sites were too close to each other, i.e. duplicate sampling. The strategy of the 2010 survey was to revisit all of the 2007 sampling sites, while the primary aim of the 2014 survey was to apply a more risk-based approach by only visiting sites that either indicated effects of TBT at or above (OSPAR) assessment class $\mathrm{C}$ in the 2010 or 2007 survey, or where the Environment Agency had recorded TBT levels in the water column above the EQS (personal communication with Ali Miles and Graham Phillips from the EA; sites indicated in Table 1).

This paper firstly looks at a spatial assessment of the 18 sites sampled in 2014 and secondly examines the results of the 1997 to 2014 surveys with a direct comparison between the same stations sampled more than once between 1997 and 2014.

\section{Materials and methods}

Sampling sites

The aim of the limited 1992 survey (14 stations) was to measure the effects TBT had on dogwhelks, to establish the geographic spread of it around England and Wales and to assess the need for a wider study. Due to the high level of TBT exposure around these coastlines, the network of sites increased from 14 sites in 1992 to 102 in 2007 (Fig. 1, Table 1). These sites include areas close to ports, e.g. Dover, Southampton Water and Milford Haven; areas close to shipping lanes (traffic separation zones), e.g. Dover Straits, Isle of Wight and Holyhead; and areas away from the influence of shipping, including "background reference" sites.
Sample collection

At each sampling site, up to 100 dogwhelks were collected from the foreshore between spring low water and mid tide levels. The location of the site was recorded using national grid references in the early survey years and in latitude and longitude using the global positioning system (GPS) in more recent years. Date and time of collection were also recorded for ICES reporting purposes.

From the 100 animals collected, 50 specimens (young adults, with toothed shells) were taken back to the laboratory for analysis; animals with worn shells were excluded from the sample as they could be older than 4 years. If no individuals were found within the first 25 min of sampling, the station was abandoned. Each sample was stored in a sealed net bag in a cool box with sea water-wetted seaweed (taken from the sampling site) until the sample was transferred to aquarium facilities in the laboratory. On transfer to these facilities (cool [4$15^{\circ} \mathrm{C}$ ], aerated and filtered sea water), the animals were stored for as short a period of time as possible before analysis. In general, this was less than $36 \mathrm{~h}$ and always less than 7 days.

Sample processing and quality assurance

Of the 50 individuals brought back from the shore, 40 were chosen at random and analysed. If an individual was parasitised or dead, it was excluded from the analysis and a fresh dogwhelk was added. Prior to the analysis, the length of each dogwhelk was measured to the nearest $0.01 \mathrm{~mm}$ with Vernier callipers and then cracked open with a vice for further analysis, which included sex determination according to Fioroni et al. (1991) and Gibbs et al. (1987), penis length measurements in males and females (if present) and the associated imposex stage in females. To identify the stages of imposex, the methods described by Gibbs et al. (1987) were used.

Quality assurance was implemented over the years by ensuring that the analysts have undergone in-house training and participated in ring tests with other organisations, such as Marine Scotland. The analysts also participated in the Quality Assurance of Information for Marine Environmental Monitoring in Europe laboratory proficiency rounds for imposex in marine snails since 2003. The highest possible score of "satisfactory" was achieved every 
Table 1 All 102 imposex sampling sites and when they were sampled

\begin{tabular}{|c|c|c|c|c|c|c|c|c|c|}
\hline Stratum & Site name & Latitude & Longitude & 1992 & 1997 & 2004 & 2007 & 2010 & 2014 \\
\hline Anglia & Dumpton Gap & 51.3494 & 1.442 & & & & $\mathrm{X}$ & & \\
\hline Anglia & Herne Bay & 51.3801 & 1.2 & & & & $\mathrm{X}$ & & \\
\hline Anglia & Palm Bay & 51.3934 & 1.4222 & & & & $\mathrm{X}$ & $\mathrm{X}$ & \\
\hline Anglia & Walpole Bay & 51.3938 & 1.405 & & & & $\mathrm{X}$ & & $\mathrm{X}$ \\
\hline Cardigan Bay & Abermawr & 51.9713 & -5.0831 & & $\mathrm{X}$ & $\mathrm{X}$ & $\mathrm{X}$ & $\mathrm{X}$ & \\
\hline Cardigan Bay & Aberystwyth & 52.4126 & -4.0921 & & $\mathrm{X}$ & $\mathrm{X}$ & $\mathrm{X}$ & $\mathrm{X}$ & \\
\hline Cardigan Bay & Cable Bay & 53.2072 & -4.5004 & & $\mathrm{X}$ & & $\mathrm{X}$ & $\mathrm{X}$ & \\
\hline Cardigan Bay & Caernarfon & 53.1403 & -4.2845 & & $\mathrm{X}$ & & & & \\
\hline Cardigan Bay & Church Bay (Anglesey) & 53.3709 & -4.5577 & & $\mathrm{X}$ & & $\mathrm{X}$ & $\mathrm{X}$ & \\
\hline Cardigan Bay & New Quay & 52.2175 & -4.3602 & & $\mathrm{X}$ & $\mathrm{X}$ & $\mathrm{X}$ & & \\
\hline Cardigan Bay & Porth Colmon & 52.8755 & -4.6824 & & $\mathrm{X}$ & $\mathrm{X}$ & $\mathrm{X}$ & $\mathrm{X}$ & \\
\hline Cardigan Bay & Puffin Island & 53.3136 & -4.0412 & & $\mathrm{X}$ & & & & \\
\hline Cardigan Bay & Sandy Beach & 53.3338 & -4.5764 & & $\mathrm{X}$ & $\mathrm{X}$ & $\mathrm{X}$ & $\mathrm{X}$ & \\
\hline Cardigan Bay & Sarn Bach & 52.8116 & -4.4987 & & $\mathrm{X}$ & & $\mathrm{X}$ & & \\
\hline Cardigan Bay & South Stack & 53.2999 & -4.6793 & & $\mathrm{X}$ & & $\mathrm{X}$ & $\mathrm{X}$ & \\
\hline Cardigan Bay & Trearddur & 53.2072 & -4.5004 & & $\mathrm{X}$ & & $\mathrm{X}$ & $\mathrm{X}$ & \\
\hline Cardigan Bay & Trefor & 52.9992 & -4.4206 & & $\mathrm{X}$ & & $\mathrm{X}$ & $\mathrm{X}$ & \\
\hline Eastern Channel & Bembridge & 50.6889 & -1.0713 & & & & $\mathrm{X}$ & $\mathrm{X}$ & \\
\hline Eastern Channel & Bill of Portland & 50.5125 & -2.4577 & $\mathrm{X}$ & $\mathrm{X}$ & & $\mathrm{X}$ & $\mathrm{X}$ & \\
\hline Eastern Channel & Brixham & 50.4004 & -3.5052 & $\mathrm{X}$ & $\mathrm{X}$ & $\mathrm{X}$ & $\mathrm{X}$ & $\mathrm{X}$ & \\
\hline Eastern Channel & East Cowes & 50.7663 & -1.276 & & & & $\mathrm{X}$ & & $\mathrm{X}^{\mathrm{a}}$ \\
\hline Eastern Channel & Eastbourne & 50.7583 & 0.2832 & $\mathrm{X}$ & $\mathrm{X}$ & $\mathrm{X}$ & $\mathrm{X}$ & $\mathrm{X}$ & \\
\hline Eastern Channel & Folkestone & 51.0849 & 1.202 & $\mathrm{X}$ & $\mathrm{X}$ & $\mathrm{X}$ & $\mathrm{X}$ & & \\
\hline Eastern Channel & Gurnard Bay & 50.7602 & -1.3254 & & & & $\mathrm{X}$ & $\mathrm{X}$ & $\mathrm{X}^{\mathrm{a}}$ \\
\hline Eastern Channel & Hanover Point & 50.6519 & -1.4652 & & & & $\mathrm{X}$ & & $\mathrm{X}$ \\
\hline Eastern Channel & Hayling Island & 50.787 & -0.9376 & $\mathrm{X}$ & & & & & \\
\hline Eastern Channel & Horse Ledge Shanklin & 50.6186 & -1.1714 & & & & $\mathrm{X}$ & $\mathrm{X}$ & $\mathrm{X}$ \\
\hline Eastern Channel & Selsey Bill & 50.7297 & -0.7761 & $\mathrm{X}$ & $\mathrm{X}$ & & $\mathrm{X}$ & $\mathrm{X}$ & \\
\hline Eastern Channel & St. Catherine's Point & 50.5758 & -1.3 & & & & $\mathrm{X}$ & $\mathrm{X}$ & \\
\hline Eastern Channel & St. Margaret's Bay & 51.1523 & 1.3892 & & & & $\mathrm{X}$ & $\mathrm{X}$ & \\
\hline Eastern Channel & Totland Bay & 50.6839 & -1.544 & & & & $\mathrm{X}$ & & $X^{a}$ \\
\hline Eastern Channel & Ventnor & 50.5919 & -1.2118 & & & & $\mathrm{X}$ & & $\mathrm{X}$ \\
\hline Eastern Channel & West Bay & 50.7113 & -2.7714 & $\mathrm{X}$ & $\mathrm{X}$ & $\mathrm{X}$ & & $\mathrm{X}$ & \\
\hline Humber/Wash & Sewerby & 54.0995 & -0.1525 & $\mathrm{X}$ & $\mathrm{X}$ & $\mathrm{X}$ & $\mathrm{X}$ & & \\
\hline Irish Sea & Cemaes Bay & 53.4153 & -4.4525 & & $\mathrm{X}$ & $\mathrm{X}$ & $\mathrm{X}$ & $\mathrm{X}$ & \\
\hline Irish Sea & Cemlyn Bay & 53.4136 & -4.5145 & & $\mathrm{X}$ & & & & \\
\hline Irish Sea & Great Ormes Head & 53.3252 & -3.8604 & & $\mathrm{X}$ & & $\mathrm{X}$ & $\mathrm{X}$ & \\
\hline Irish Sea & Llanbadrig & 53.441 & -4.45 & & $\mathrm{X}$ & $\mathrm{X}$ & & $\mathrm{X}$ & \\
\hline Irish Sea & Llanellen & 53.4113 & -4.2933 & & $X$ & & $\mathrm{X}$ & $X$ & \\
\hline Irish Sea & Maryport & 54.7224 & -3.5003 & & $\mathrm{X}$ & $\mathrm{X}$ & $\mathrm{X}$ & & $\mathrm{X}$ \\
\hline Irish Sea & Moelfre & 53.353 & -4.2346 & & $\mathrm{X}$ & & $\mathrm{X}$ & $\mathrm{X}$ & \\
\hline Irish Sea & Rhos-on-Sea & 53.3085 & -3.7367 & & $\mathrm{X}$ & $\mathrm{X}$ & $\mathrm{X}$ & $\mathrm{X}$ & \\
\hline Irish Sea & Roa Island & 54.0726 & -3.1735 & & $X$ & $X$ & $X$ & $X$ & $\mathrm{X}^{\mathrm{a}}$ \\
\hline Irish Sea & St. Bees Head & 54.4898 & -3.6122 & & $\mathrm{X}$ & $\mathrm{X}$ & $\mathrm{X}$ & $\mathrm{X}$ & $\mathrm{X}^{\mathrm{a}}$ \\
\hline
\end{tabular}


Table 1 (continued)

\begin{tabular}{|c|c|c|c|c|c|c|c|c|c|}
\hline Stratum & Site name & Latitude & Longitude & 1992 & 1997 & 2004 & 2007 & 2010 & 2014 \\
\hline Irish Sea & Whitehaven & 54.5591 & -3.5913 & & $\mathrm{X}$ & & $\mathrm{X}$ & $\mathrm{X}$ & \\
\hline Severn & Angle Bay & 51.688 & -5.0754 & & $X$ & & $\mathrm{X}$ & $\mathrm{X}$ & \\
\hline Severn & Barry Island & 51.3858 & -3.2783 & & & & $\mathrm{X}$ & $\mathrm{X}$ & \\
\hline Severn & Combe Martin & 51.2091 & -4.0414 & & $\mathrm{X}$ & $\mathrm{X}$ & $\mathrm{X}$ & $\mathrm{X}$ & \\
\hline Severn & Dale Fort & 51.7039 & -5.1524 & & $\mathrm{X}$ & $\mathrm{X}$ & $\mathrm{X}$ & $\mathrm{X}$ & \\
\hline Severn & Freshwater West & 51.6536 & -5.0611 & & $X$ & $\mathrm{X}$ & $\mathrm{X}$ & $\mathrm{X}$ & \\
\hline Severn & Hartland Quay & 50.996 & -4.5336 & & $\mathrm{X}$ & $\mathrm{X}$ & $\mathrm{X}$ & $\mathrm{X}$ & \\
\hline Severn & Holywell Bay & 50.3906 & -5.1477 & & $\mathrm{X}$ & & & & \\
\hline Severn & Lavernock Point & 51.4054 & -3.1669 & & $X$ & $\mathrm{X}$ & $X$ & $\mathrm{X}$ & \\
\hline Severn & Limpert Bay & 51.3834 & -3.4144 & & & & $\mathrm{X}$ & $\mathrm{X}$ & \\
\hline Severn & Manorbier & 51.643 & -4.8063 & & $\mathrm{X}$ & $\mathrm{X}$ & $\mathrm{X}$ & $\mathrm{X}$ & \\
\hline Severn & Marloes Sands & 51.7226 & -5.2167 & & $\mathrm{X}$ & $\mathrm{X}$ & $\mathrm{X}$ & $\mathrm{X}$ & \\
\hline Severn & Martin's Haven & 51.7365 & -5.2445 & & $X$ & $\mathrm{X}$ & $\mathrm{X}$ & $\mathrm{X}$ & \\
\hline Severn & Monk Haven & 51.7097 & -4.1454 & & $\mathrm{X}$ & $\mathrm{X}$ & $\mathrm{X}$ & $\mathrm{X}$ & \\
\hline Severn & Penarth & 51.3938 & -3.1605 & & & & $\mathrm{X}$ & & \\
\hline Severn & Pennar Jetty & 51.6888 & -4.9777 & & $\mathrm{X}$ & & & & \\
\hline Severn & Pennar Point & 51.6919 & -4.9662 & & $\mathrm{X}$ & & $\mathrm{X}$ & $\mathrm{X}$ & \\
\hline Severn & Perranporth & 50.348 & -5.1582 & & $\mathrm{X}$ & & $\mathrm{X}$ & $\mathrm{X}$ & \\
\hline Severn & Polzeath & 50.5743 & -4.9216 & & $\mathrm{X}$ & $\mathrm{X}$ & $\mathrm{X}$ & $\mathrm{X}$ & \\
\hline Severn & Porlock Weir & 51.2192 & -3.6235 & & $X$ & $X$ & $X$ & $X$ & \\
\hline Severn & Port Eynon & 51.5408 & -4.2063 & & $\mathrm{X}$ & $\mathrm{X}$ & $\mathrm{X}$ & $\mathrm{X}$ & \\
\hline Severn & Porth Beach & 50.426 & -5.0628 & & $\mathrm{X}$ & $\mathrm{X}$ & $\mathrm{X}$ & $\mathrm{X}$ & \\
\hline Severn & Porthcorthan & 50.5098 & -5.0303 & & $\mathrm{X}$ & $\mathrm{X}$ & $\mathrm{X}$ & $\mathrm{X}$ & \\
\hline Severn & Porthtowan & 50.2871 & -5.2454 & & $\mathrm{X}$ & $\mathrm{X}$ & $\mathrm{X}$ & $\mathrm{X}$ & \\
\hline Severn & Portquin & 50.5897 & -4.8694 & & $\mathrm{X}$ & & $\mathrm{X}$ & $\mathrm{X}$ & \\
\hline Severn & Renny’s Slip & 51.7324 & -5.2447 & & $\mathrm{X}$ & $\mathrm{X}$ & & $\mathrm{X}$ & \\
\hline Severn & Sennen Cove & 50.0785 & -5.7034 & & $\mathrm{X}$ & $X$ & $\mathrm{X}$ & $\mathrm{X}$ & \\
\hline Severn & Stackpole Quay & 51.6241 & -4.8999 & & $\mathrm{X}$ & $\mathrm{X}$ & $\mathrm{X}$ & $\mathrm{X}$ & \\
\hline Severn & Tenby & 51.6792 & -4.6989 & & $\mathrm{X}$ & $\mathrm{X}$ & $\mathrm{X}$ & $\mathrm{X}$ & $\mathrm{X}$ \\
\hline Severn & Trenance & 50.4656 & -5.0344 & & $X$ & & & & \\
\hline Severn & Trevone & 50.5456 & -4.981 & & $\mathrm{X}$ & & & & \\
\hline Severn & Treknow & 50.6452 & -4.7624 & & $\mathrm{X}$ & & $\mathrm{X}$ & $\mathrm{X}$ & \\
\hline Severn & Watwick Bay & 51.6921 & -5.1601 & & $\mathrm{X}$ & $\mathrm{X}$ & $\mathrm{X}$ & $\mathrm{X}$ & \\
\hline Severn & West Angle Bay & 51.6859 & -5.1102 & & $\mathrm{X}$ & $\mathrm{X}$ & $\mathrm{X}$ & $\mathrm{X}$ & \\
\hline Severn & West Pentire & 50.4056 & -5.131 & & $\mathrm{X}$ & & & & \\
\hline Severn & Westdale Bay & 51.7073 & -5.1881 & & $\mathrm{X}$ & $\mathrm{X}$ & $\mathrm{X}$ & $\mathrm{X}$ & \\
\hline Severn & Whitesands Bay & 51.898 & -5.2986 & & $X$ & $X$ & $\mathrm{X}$ & & \\
\hline Tyne Tees & Amble & 55.3377 & -1.5714 & & & $\mathrm{X}$ & & $\mathrm{X}$ & \\
\hline Tyne Tees & Blyth & 55.1306 & -1.5001 & & & $\mathrm{X}$ & $\mathrm{X}$ & $\mathrm{X}$ & \\
\hline Tyne Tees & Blyth Ferry & 55.1242 & -1.4892 & $\mathrm{X}$ & $\mathrm{X}$ & & & & \\
\hline Tyne Tees & Boulmer & 55.4241 & -1.5774 & $\mathrm{X}$ & $X$ & $\mathrm{X}$ & $\mathrm{X}$ & $\mathrm{X}$ & \\
\hline Tyne Tees & Hartlepool & 54.7 & -1.1794 & & & $\mathrm{X}$ & $\mathrm{X}$ & $\mathrm{X}$ & $\mathrm{X}$ \\
\hline Tyne Tees & Parson's Rock & 54.9316 & -1.3659 & & & & $\mathrm{X}$ & $\mathrm{X}$ & $\mathrm{X}$ \\
\hline Tyne Tees & Robin Hood's Bay & 54.4232 & -0.5277 & & & & $\mathrm{X}$ & $\mathrm{X}$ & \\
\hline
\end{tabular}


Table 1 (continued)

\begin{tabular}{|c|c|c|c|c|c|c|c|c|c|}
\hline Stratum & Site name & Latitude & Longitude & 1992 & 1997 & 2004 & 2007 & 2010 & 2014 \\
\hline Tyne Tees & Saltburn & 54.5869 & -0.951 & & & & $\mathrm{X}$ & $\mathrm{X}$ & \\
\hline Tyne Tees & Scarborough & 54.2881 & -0.3957 & & & & $\mathrm{X}$ & $\mathrm{X}$ & \\
\hline Tyne Tees & St. Mary's Lighthouse & 55.0717 & -1.4525 & & & $\mathrm{X}$ & & $\mathrm{X}$ & \\
\hline Tyne Tees & Tees & 54.648 & -1.1534 & & & & $\mathrm{X}$ & $\mathrm{X}$ & $\mathrm{X}$ \\
\hline Tyne Tees & Tynemouth (Outside) & 55.019 & -1.4176 & & & & $\mathrm{X}$ & $\mathrm{X}$ & \\
\hline Tyne Tees & Whitby & 54.4907 & -0.6093 & $\mathrm{X}$ & $\mathrm{X}$ & $\mathrm{X}$ & $\mathrm{X}$ & $\mathrm{X}$ & $\mathrm{X}$ \\
\hline Tyne Tees & Whitley Bay & 55.039 & -1.4312 & & & & $\mathrm{X}$ & $\mathrm{X}$ & \\
\hline Western Channel & Bovisand & 50.3349 & -4.1208 & $\mathrm{X}$ & $\mathrm{X}$ & $\mathrm{X}$ & $\mathrm{X}$ & $\mathrm{X}$ & $\mathrm{X}^{\mathrm{a}}$ \\
\hline Western Channel & Gwennap Head & 50.0367 & -5.6716 & $\mathrm{X}$ & $\mathrm{X}$ & $\mathrm{X}$ & $\mathrm{X}$ & $\mathrm{X}$ & \\
\hline Western Channel & St. Agnes & 50.3222 & -5.2043 & & $\mathrm{X}$ & & & & \\
\hline Western Channel & St. Mawes & 50.1554 & -5.0251 & & & & $\mathrm{X}$ & $\mathrm{X}$ & $\mathrm{X}$ \\
\hline Western Channel & Start Point & 50.2197 & -3.6501 & $\mathrm{X}$ & $\mathrm{X}$ & $\mathrm{X}$ & $\mathrm{X}$ & $\mathrm{X}$ & \\
\hline Western Channel & Swanpool & 50.1396 & -5.0763 & & & & $\mathrm{X}$ & $\mathrm{X}$ & $\mathrm{X}$ \\
\hline Western Channel & Towan Head & 50.1563 & -4.984 & & $\mathrm{X}$ & & $\mathrm{X}$ & $\mathrm{X}$ & \\
\hline
\end{tabular}

${ }^{a}$ Additional 6 sites sampled in 2014 for the Environment Agency

time an analyst participated. The last round for imposex in marine snails took place in 2012. The same analyst of the 2010 and 2014 surveys participated in the 2012 round.
Calculation of imposex parameter

After all the individuals were measured, the Vas Deferens Sequence Index (VDSI) was calculated as

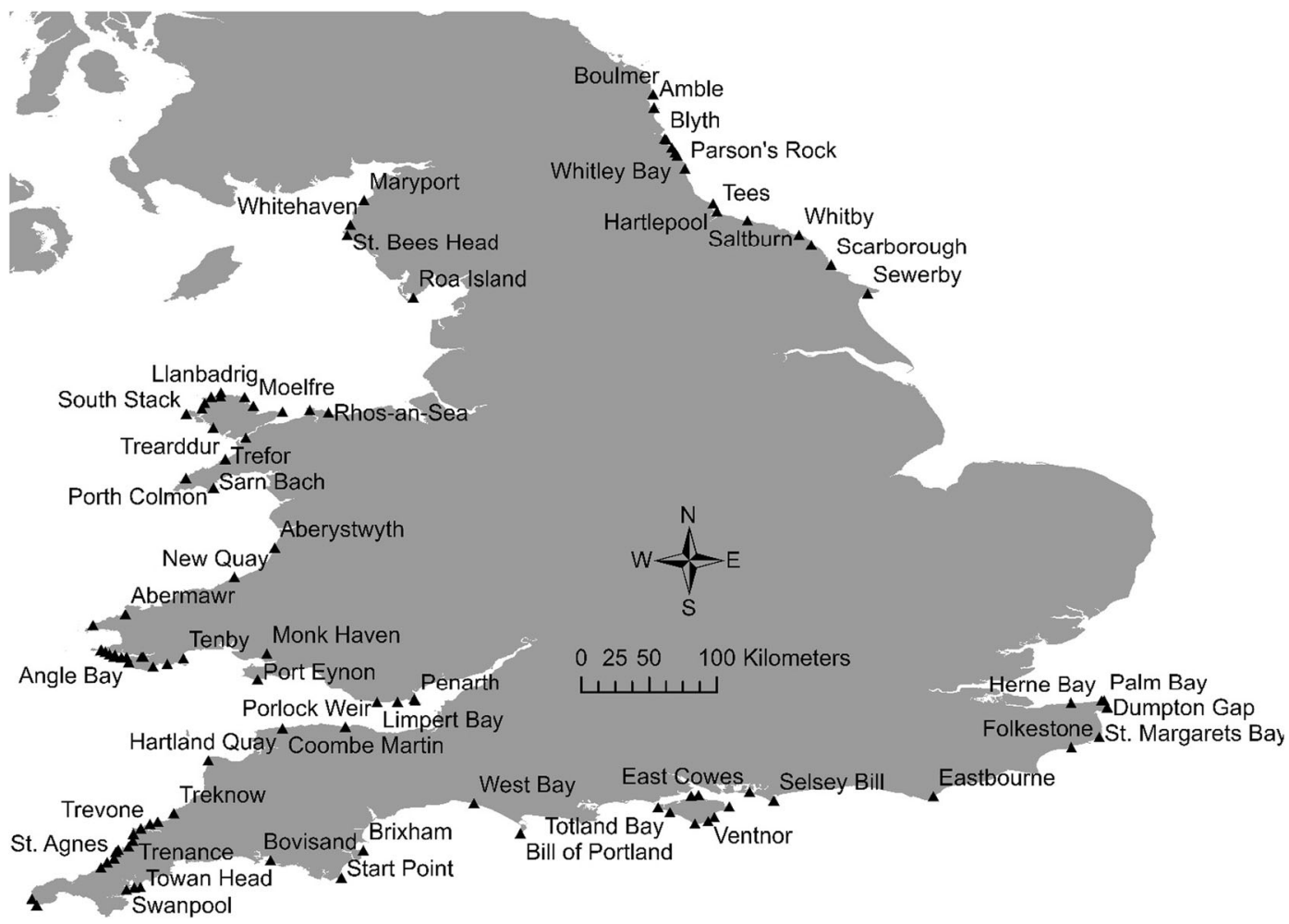

Fig. 1 All 102 imposex sampling sites in England and Wales 
Table 2 Interpretations of the assessment classes, referring to Nucella lapillus used in the Oslo and Paris Convention (OSPAR) monitoring guideline (OSPAR 2004)

\begin{tabular}{|c|c|c|}
\hline OSPAR ass. class & Nucella lapillus VDSI & Effects and impacts \\
\hline A & VDSI $=<0.3$ & $\begin{array}{l}\text { The level of imposex in the more sensitive gastropod species is } \\
\text { close to } 0(0-\sim 30 \% \text { of females have imposex) indicating exposure } \\
\text { to TBT concentrations close to } 0 \text {, which is the objective in the OSPAR } \\
\text { hazardous substances strategy. }\end{array}$ \\
\hline B & $\mathrm{VDSI}=0.3-<2.0$ & $\begin{array}{l}\text { The level of imposex in the more sensitive gastropod species } \\
\text { ( } \sim 30-\sim 100 \% \text { of the females have imposex) indicates exposure to TBT } \\
\text { concentrations below the Ecotoxicological Assessment Criteria (EAC) } \\
\text { derived by OSPAR for TBT, e.g. adverse effects in the more sensitive } \\
\text { taxa of the ecosystem caused by long-term exposure to TBT are } \\
\text { predicted to be unlikely to occur. }\end{array}$ \\
\hline $\mathrm{C}$ & $\mathrm{VDSI}=2.0-<4.0$ & $\begin{array}{l}\text { The level of imposex in the more sensitive gastropod species indicates } \\
\text { exposure to TBT concentrations higher than the EAC derived for TBT, } \\
\text { e.g. there is a risk of adverse effects, such as reduced growth and recruitment, } \\
\text { in the more sensitive taxa of the ecosystem caused by long-term exposure to TBT. }\end{array}$ \\
\hline $\mathrm{D}$ & $\mathrm{VDSI}=4.0-5.0$ & $\begin{array}{l}\text { The reproductive capacity in the populations of the more sensitive } \\
\text { gastropod species, such as Nucella lapillus, is affected as a result of the } \\
\text { presence of sterile females, but some reproductively capable females } \\
\text { remain, e.g. there is evidence of adverse effects, which can be directly } \\
\text { associated with the exposure of TBT. }\end{array}$ \\
\hline $\mathrm{E}$ & $\mathrm{VDSI}=>5.0$ & $\begin{array}{l}\text { Populations of the more sensitive gastropod species, such as Nucella lapillus, } \\
\text { are unable to reproduce. The majority, if not all females within the population, } \\
\text { have been sterilised. }\end{array}$ \\
\hline $\mathrm{F}$ & VDSI=- & $\begin{array}{l}\text { The populations of the more sensitive gastropod species, such as Nucella lapillus, } \\
\text { are absent/expired. }\end{array}$ \\
\hline
\end{tabular}

VDSI Vas Deferens Sequence Index

the mean of the Vas Deferens Sequence stages (VDS) observed in one sample to assess the Oslo and Paris Convention (OSPAR) class for each site (Table 2, OSPAR 2004).

\section{Statistical analysis}

The data were analysed to see whether there was evidence of a trend in mean VDS (VDSI) over time. Trends were assessed by station to avoid biases due to not all stations being sampled on every survey occasion. The survey years used were 1997, 2004, 2007, 2010 and 2014. Stations were included if they were sampled on at least two survey years. This meant that 88 stations were included and only 15 omitted. The 1992 survey could not be included in the assessment as the original VDS values for each dogwhelk were not available (similar to the paper published by Oliveira et al. 2009).

A non-parametric Mann-Kendall (MK) statistic was used to investigate trend. For trend at a single station, the Mann-Kendall method is used as follows. For each VDS observation (except for those in the final survey), the
Mann-Kendall (MK) statistic (Mann 1945; Kendall $1975)$ is the sum of the number of observations from later surveys that are greater than it $(+1$ per observation) and the number of observations that are less than it $(-1$ per observation). This is repeated for all time points and the cumulative sum is calculated. We denote this as the MK statistic.

To assign a $p$ value to the observed MK statistic, a two-sided randomisation test (Manly 2006) was used. Under the null hypothesis of no trend, the VDS observations can be randomly permuted (keeping the survey year vector fixed). Then, the MK statistic can be calculated as above. This procedure was carried out 999 times in total to estimate the null distribution of the MK statistic. The number of the absolute values of these observations that are greater than the absolute value of the observed MK statistic is noted (call this BIGGER). Following Manly, the $p$ value is calculated as (BIGGER+1)/1000.

For the trend analysis, we have assumed that the samples taken at each station were a reasonably representative spatial sample and that the VDS values within 


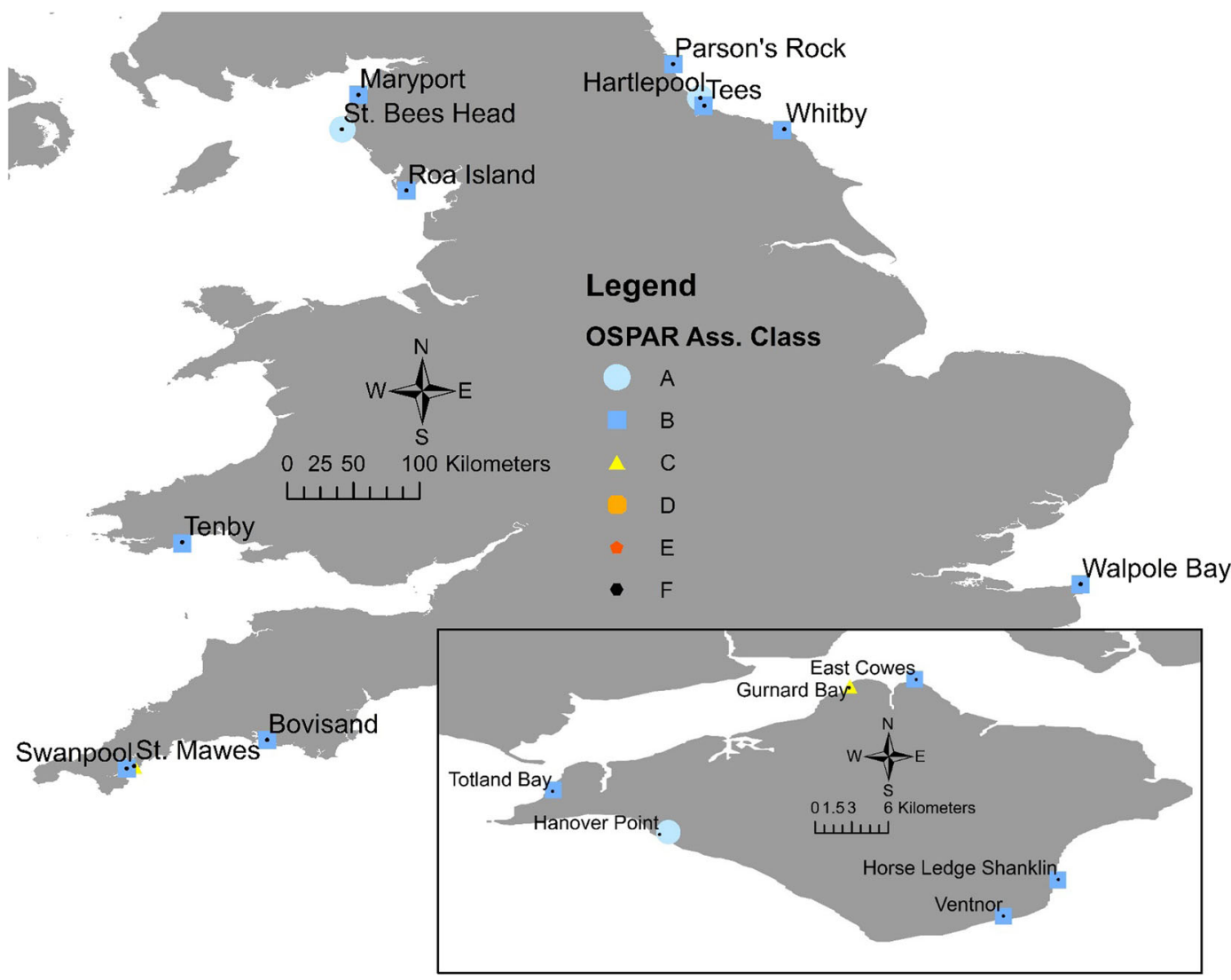

Fig. 2 Oslo and Paris Convention classification of dogwhelks from 2014 England and Wales sampling sites; OSPAR classifications go from A (background incidence of imposex) to F (populations of the more sensitive gastropod species are absent/expired)

a station were independent. Because we cannot be sure whether this assumption holds fully, we also looked at trends between 1997 and 2010 but by analysing the mean VDS values at each station - and hence negating the need for independence between samples within a station. We considered the 56 stations that were sampled in both 1997 and 2010. For each station, we calculated the mean level of VDS. We then compared the 56 VDSI sampled in 1997 with the same 56 VDSI sampled in 2010 using a paired (between stations) non-parametric Wilcoxon test. The same approach was carried out for the 6 stations that were sampled in both 1997 and 2014 . While this is a less powerful comparison, it allows us to examine the most recent data.

\section{Results}

The results of the 2014 survey show that 2 sites (St. Mawes and Gurnard Bay) still exceed the
Ecotoxicological Assessment Criteria (EAC) for TBT exposure with an OSPAR assessment class $\mathrm{C}$, while 3 and 13 sites are at OSPAR assessment class A and B, respectively (Fig. 2 for spatial overview; Table 3 for summary information). Comparing the same 12 sites sampled between 2010 and 2014 shows that three sites (Gurnard Bay, Roa Island and Bovisand) increased in the VDSI (Table S1), with Gurnard Bay and Roa Island also changing to a higher OSPAR assessment class (Table 4). The other nine sites sampled in 2010 and 2014 (Table 1) showed reductions in VDSI with 8 also changing to a lower OSPAR assessment class (Table 4). By comparing the summary results shown in Table 4 of the TBT OSPAR assessment classes, it seemed that there were large decreases in the effects of TBT on N. lapillus between 1992 and 2014 in England and Wales.

While recognising that comparisons between years are not strictly appropriate because the same stations are not always sampled in the same year, it is interesting to 
Table 3 Summary results of the 2014 imposex survey separated into strata

\begin{tabular}{|c|c|c|c|c|}
\hline Stratum & Site name & Number & VDSI \pm St. Dev. 2014 & OSPAR ass. class \\
\hline Anglia & Walpole Bay & 18 & $0.94 \pm 1.1$ & $\mathrm{~B}$ \\
\hline Eastern Channel & Hanover Point & 22 & $0.14 \pm 0.35$ & $\mathrm{~A}$ \\
\hline Eastern Channel & Horse Ledge Shanklin & 25 & $1.32 \pm 1.25$ & $\mathrm{~B}$ \\
\hline Eastern Channel & Ventnor & 14 & $1.07 \pm 1.21$ & $\mathrm{~B}$ \\
\hline Eastern Channel & East Cowes ${ }^{\mathrm{a}}$ & 19 & $0.68 \pm 0.82$ & B \\
\hline Eastern Channel & Gurnard Bay $^{\mathrm{a}}$ & 14 & $2.07 \pm 1.27$ & $\mathrm{C}$ \\
\hline Eastern Channel & Totland Bay ${ }^{\mathrm{a}}$ & 28 & $0.46 \pm 0.69$ & $\mathrm{~B}$ \\
\hline Irish Sea & Maryport & 20 & $1.30 \pm 1.66$ & $\mathrm{~B}$ \\
\hline Irish Sea & Roa Island $^{\mathrm{a}}$ & 15 & $0.80 \pm 1.01$ & $\mathrm{~B}$ \\
\hline Irish Sea & St. Bees Head ${ }^{a}$ & 18 & $0.00 \pm 0.00$ & A \\
\hline Severn & Tenby & 27 & $1.78 \pm 1.55$ & $\mathrm{~B}$ \\
\hline Tyne Tees & Hartlepool & 21 & $0.28 \pm 0.56$ & $\mathrm{~A}$ \\
\hline Tyne Tees & Parsons Rock & 18 & $0.72 \pm 0.89$ & $\mathrm{~B}$ \\
\hline Tyne Tees & Tees & 21 & $1.38 \pm 1.12$ & $\mathrm{~B}$ \\
\hline Tyne Tees & Whitby & 22 & $1.18 \pm 1.18$ & $\mathrm{~B}$ \\
\hline Western Channel & St. Mawes & 21 & $2.57 \pm 1.36$ & $\mathrm{C}$ \\
\hline Western Channel & Swanpool & 16 & $1.68 \pm 1.45$ & $\mathrm{~B}$ \\
\hline Western Channel & Bovisand $^{\mathrm{a}}$ & 23 & $0.91 \pm 1.00$ & $\mathrm{~B}$ \\
\hline
\end{tabular}

VDSI Vas Deferens Sequence Index, OSPAR ass. class assessment class as highlighted in Table 2

${ }^{\text {a }}$ Six additional sites sampled for the Environment Agency

see how the percentages in the various OSPAR assessment classes changed over years. Not one station out of 14 of the 1992 England and Wales survey was at background imposex level, class A on the OSPAR assessment scale, whereas $100 \%$ of stations were at classes $\mathrm{C}$ or D. In contrast, in $2010,43 \%$ of the 77 sites were class A, followed by 47,9 and $1 \%$ for $\mathrm{B}, \mathrm{C}$ and $\mathrm{D}$, respectively. In the intervening surveys, 1997, 2004 and 2007, there was a gradual improvement in the level of imposex in each class recorded as shown by the changes in the proportion of imposex within each class (Table 5). The summary statistics of the imposex development in England and Wales between 1992 and 2014 indicate an increase in the number of sites at OSPAR assessment classes A and B (from $0 \%$ for A and B in 1992 to 17 and $72 \%$ in 2014, respectively; Table 5).

AVDSI trend assessment between the 1997 and 2014 surveys was carried out with the non-parametric MannKendall statistic. The results highlighted in Table 4 show that 65 sites out of 88 reduced statistically significantly in VDSI. The Gurnard Bay site showed a significant increase in VDSI. Twenty sites showed not significant reductions and two not significant increases in
VDSI (Table 4). A direct comparison of the same 56 sites sampled in the 1997 and 2010 surveys showed that the VDSI reduced from 2.89 and 0.42 , respectivelythis difference was strongly statistically significant $(p>0.001)$. Another comparison of the same 6 sites sampled in 1997 and 2014 showed a statistically significant VDSI reduction from 3.14 in 1997 to 1 in 2014 $(p=0.03)$. The summary information of the observed VDSI can be found in Table S1 in the supplementary section.

\section{Discussion}

Over the past two decades of regular surveys, there has been a consistent decrease in imposex levels corresponding to the implementation of different legislation controlling the use of TBT (Birchenough et al. 2002; Bryan et al. 1993). The results described in the 2014 survey show a continued decline in the incidence of imposex since the 1997 survey when looking at the same 6 stations. 







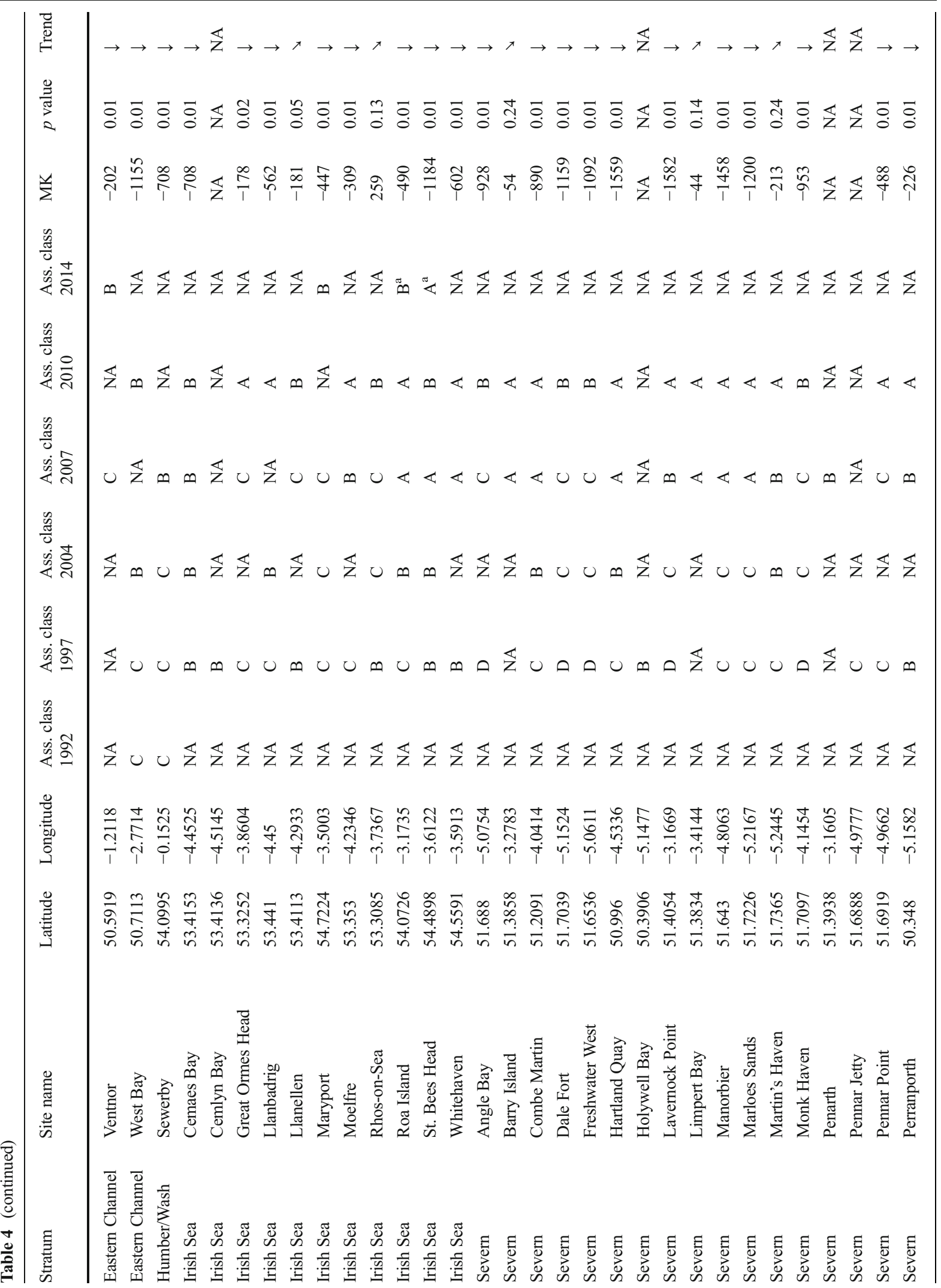











Table 5 Percentage of sites in each OSPAR assessment class for imposex for each reporting year between 1992 and 2014 for England and Wales

\begin{tabular}{|c|c|c|c|c|c|c|c|}
\hline \multirow[b]{2}{*}{ Sampling year } & \multirow[b]{2}{*}{ Sampling sites } & \multicolumn{6}{|c|}{$\begin{array}{l}\% \text { of sites in each } \\
\text { OSPAR ass. class }\end{array}$} \\
\hline & & $\mathrm{F}$ & $\mathrm{E}$ & $\mathrm{D}$ & $\mathrm{C}$ & B & A \\
\hline 1992 & 14 & 0 & 0 & 57 & 43 & 0 & 0 \\
\hline 1997 & 72 & 1 & 0 & 17 & 53 & 29 & 0 \\
\hline 2004 & 48 & 0 & 0 & 0 & 67 & 27 & 6 \\
\hline 2007 & 86 & 0 & 0 & 0 & 35 & 49 & 16 \\
\hline 2010 & 77 & 0 & 0 & 1 & 9 & 47 & 43 \\
\hline 2014 & 18 & 0 & 0 & 0 & 11 & 72 & 17 \\
\hline
\end{tabular}

OSPAR ass. class Oslo and Paris Convention assessment class as highlighted in Table 2

The decline has been most marked in 2007 and 2010, probably as a result of the phasing out and complete supposed removal of TBT antifouling paints from boats on 17 September 2008. These results are similar to a study for sites around Portugal by Galante-Oliveira et al. (2011). A general decrease was observed in Portugal: whereas $56 \%$ of dogwhelks had a VDSI value of 2 or higher in 2006, in 2008, only $17 \%$ showed a similar level of effect. This correlates well with our study, where $35 \%$ of dogwhelks had VDSI values greater than 2 in 2007 and only $10 \%$ in 2010 . The OSPAR monitoring community also observed a downward trend in VDSI. Over $80 \%$ of sites showing a downward trend and $16 \%$ showed a non-improvement, while $4 \%$ show a stable background concentration level (OSPAR 2014).

Currently, the only source of TBT in the marine environment is from historical/residual contamination in sediments in estuaries and harbours (Sousa et al. 2009) and arising from dredged material disposal, but this activity is tightly controlled and is unlikely to be a significant source of contamination in the future as disposal sites are chosen to be dispersive and insuring that sediments will not stay on one site within England and Wales. Nevertheless, two sites (St. Mawes and Gurnard Bay) measured OSPAR assessment class C in 2014, failing the EAC that was derived for TBT, meaning that there is a risk of adverse effects, such as reduced growth and recruitment (OSPAR 2004). Langston et al. (2015) observed a VDSI of 2.76 in St. Mawes in 2012 which is between the 2010 and 2014 survey result of these surveys ( 3.73 and 2.57, respectively). Currently, it is difficult to understand why there has not been a 
significant decrease at these sites. Local illegal use of TBT antifouling paint cannot be ruled out, but it is more likely that historic pollution in sediments may act as a source of TBT for a longer time period in certain areas (OSPAR 2013b). Gibbs (2009) observed little improvement in the reproductive capacity of the population at a shipyard near Falmouth. The TBT pollution in his study area was probably a result of discharges from the shipyards or release or re-suspension from sediments. This could be another explanation for the continuing TBT impacts. His results correlate with the constantly high levels at St. Mawes station Falmouth in our study. As imposex is irreversible in dogwhelks (Bryan et al. 1986) and since they live for up to 7 years, it will take time for the most affected animals (class $\mathrm{C}$ and above) to disappear from the population. Nevertheless, clear evidence that dogwhelk populations are recovering at all sites is shown by the presence of juveniles and eggs recorded at each site. Eggs were present at many of the sites, but juveniles were observed at all 77 sites in the 2010 survey and all 18 sites in the 2014 survey. Because dogwhelks do not have a pelagic dispersal phase in their life cycle, it indicates that all populations are actively and successfully reproducing. In 1997, $N$. lapillus was deemed extinct from the Bill of Portland, but due to the ability to re-colonise areas where extinction has occurred (Huet et al. 2004), these organisms were observed again from 2007 onwards.

\section{Conclusions}

Imposex in dogwhelks was attributed to TBT-based antifouling paints used on yachts and ships in the UK in the 1980s (Gibbs and Bryan 1986). Since then, the UK Government has actively pursued legislation to control the use of TBT in the marine environment and supported UK-wide marine monitoring surveys of imposex. As a result, the evidence shown here clearly demonstrates the efficacy of the policy in improving dogwhelk health and in many England and Wales foreshores. The data set shows a good example of science and policy working handin-hand for environmental benefit. The continued measurement of imposex in marine molluscs offers the most clear-cut tool for monitoring of a contaminant-specific pollution effect under the Marine Strategy Framework Directive (OSPAR 2014).
Acknowledgments We thank the Department of Environment, Food and Rural Affairs (Defra) for funding the 2014 survey under contract SLA22 and the 2010 survey under contract SLA26 and giving us the opportunity to write up this study under the contract SLA22. We also thank all of those involved in collecting samples over the years including Sarah Lincoln, Rachel Beckett, Ruth Hicks, Julie Bremner, Jacqueline Eggleton, Andy Smith, Andrew Griffith, Paul Mcllwaine and John Thain. A special thank you goes to Robin Law and Mike Waldock for their useful comments while collating the study.

Funding of the older surveys was also provided by Defra and its predecessor, MAFF. Defra and MAFF were not directly involved in the study design; in the collection, analysis or interpretation of data; or in the preparation of the manuscript. The paper was submitted to Defra prior to submission for approval, which was given.

\section{Compliance with ethical standards}

Conflict of interest The authors declare that they have no competing interests.

Ethics approval All applicable international, national and/or institutional guidelines for the care and use of animals were followed.

Open Access This article is distributed under the terms of the Creative Commons Attribution 4.0 International License (http:// creativecommons.org/licenses/by/4.0/), which permits unrestricted use, distribution, and reproduction in any medium, provided you give appropriate credit to the original author(s) and the source, provide a link to the Creative Commons license, and indicate if changes were made.

\section{References}

Birchenough, A. C., Barnes, N., Evans, S. M., Hinz, H., Krönke, I., \& Moss, C. (2002). A review and assessment of tributyltin contamination in the North Sea, based on surveys of butyltin tissues burdens and imposex/intersex in four species of neogastropods. Marine Pollution Bulletin, 44, 534-543.

Bryan, G. W., Gibbs, P. E., Hummerstone, L. G., \& Burt, G. R. (1986). The decline of the gastropod Nucella lapillus around south-west England: evidence for the effect of tributyltin from antifouling paints. Journal of the Marine Biological Association of the UK, 66, 611-640.

Bryan, G. W., Burt, G. R., Gibbs, P. E., \& Pascoe, P. L. (1993). Nassarius reticulatus (Nassariidae: Gastropoda) as an indicator of tributyltin pollution before and after TBT restrictions. Journal of the Marine Biological Association of the UK, 73, 913-929.

Fioroni, P., Oehlmann, J., \& Stroben, E. (1991). The pseudohermaphroditism of prosobranchs; morphological aspects. Zoologischer Anzeiger, 226, 1-26.

Galante-Oliveira, S., Oliveira, I., Ferreira, N., Santos, J. S., Pacheco, M., \& Barroso, C. (2011). Nucell lapillus L. imposex levels after legislation prohibiting TBT antifoulants: 
temporal trends from 2003 to 2008 along the Portuguese coast. Journal of Environmental Monitoring, 13, 304-312.

Gibbs, P. E. (2009). Long-term tributyltin (TBT)-induced sterilization of neogastropods: persistence of effects in Ocenebra erinacea over 20 years in the vicinity of Falmouth (Cornwall, UK). Journal of the Marine Biological Association of the $U K, 89,135-138$.

Gibbs, P. E., \& Bryan, G. W. (1986). Reproductive failure in populations of the dogwhelk, Nucella lapillus, caused by imposex induced by tributyltin from antifouling paints. Journal of the Marine Biological Association of the UK, 67, 507-23.

Gibbs, P. E., Bryan, G. W., Pascoe, P. L., \& Burt, G. R. (1987). The use of dog-whelk Nucella lapillus, as an indicator of tributyltin (TBT) contamination. Journal of the Marine Biological Association of the UK, 67, 507-523.

Huet, M., Paulet, Y. M., \& Clavier, J. (2004). Imposex in Nucella lapillus: a ten year survey in NW Brittany. Marine Ecology Progress Series, 270, 153-161.

Kendall, M. G. (1975). Rank correlation methods (4th ed.). London: Charles Griffin.

Langston, W. J., Pope, N. D., Davey, M., Langston, K. M., O' Hara, S. C. M., Gibbs, P. E., \& Pascoe, P. L. (2015). Recovery from TBT in English Channel environments: A problem solved? Marine Pollution Bulletin, 95, 551-564.

Manly, B. F. J. (2006). Randomization, bootstrap and Monte Carlo methods in biology: 3rd edition. Chapman and Hall.

Mann, H. B. (1945). Nonparametric tests against trend. Econometrica, 13, 245-259.

Oehlmann, J., Stroben, E., \& Fiorini, P. (1991). The morphological expression of imposex in Nucella lapillus (Linnaeus)
(Gastropoda: Muricidae). Journal of Molluscan Studies, 57, 375-390.

Oliveira, I. B., Richardson, C. A., Sousa, A. C., Takahashi, S., Tanabe, S., \& Miguez Barroso, C. (2009). Spatial and temporal evolution of imposex in dogwhelk Nucella lapillus (L.) populations from North Wales, UK. Journal of Environmental Monitoring, 11, 1462-1468.

OSPAR (2004). Provisional JAMP assessment criteria for TBTspecific biological effects. Reference Number: 2004-15, 1-3.

OSPAR (2013a). Background document and technical annexes for biological effects monitoring, Update 2013. Publication Number: 589/2013.

OSPAR (2013b). Levels and trends in marine contaminants and their biological effects-CEMP Assessment report 2012, Publication Number: 596/2013.

OSPAR (2014). Imposex and TBT: status, trends and effects in marine molluscs: an improving situation? Reference Number: HASEC14/AS01, http://www.ospar.org/site/assets/ files/7413/ospar_assessment_sheet_cemp_imposex_2014. pdf

Santos, M. M., ten Hallers-Tjabbes, C. C., Vieira, N., Boon, P., \& Porte, C. (2002). Cytochrome P450 differences in normal and imposex-affected female Buccinum undatum from the open North Sea. Marine Environmental Research, 54, 3-5.

Sousa, A., Laranjeiro, F., Takajashi, S., Tanabe, S., \& Barraso, C. M. (2009). Imposex and organotin prevalence in a European post-legislative scenario: temporal trends from 2003 to 2008 . Chemosphere, 77, 566-573.

Waldock, M. J., Waite, M. E., \& Thain, J. E. (1988). Inputs of TBT to the marine environment from shipping activity in the UK. Environmental Technology Letters, 9, 999-1010. 